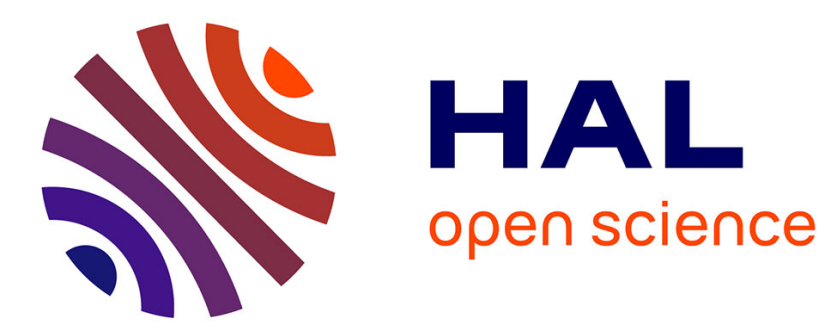

\title{
Affluence of Data on Volcanism in The Gulf of Cadiz E Wulff-Barreiro
}

\section{To cite this version:}

E Wulff-Barreiro. Affluence of Data on Volcanism in The Gulf of Cadiz. CODATA Data Science Journal, 2009, 8, pp.105-112. 10.1016/S0025-3227(02)00686-2 . hal-01241717

\section{HAL Id: hal-01241717 https://hal.science/hal-01241717}

Submitted on 10 Dec 2015

HAL is a multi-disciplinary open access archive for the deposit and dissemination of scientific research documents, whether they are published or not. The documents may come from teaching and research institutions in France or abroad, or from public or private research centers.
L'archive ouverte pluridisciplinaire HAL, est destinée au dépôt et à la diffusion de documents scientifiques de niveau recherche, publiés ou non, émanant des établissements d'enseignement et de recherche français ou étrangers, des laboratoires publics ou privés. 


\title{
AFFLUENCE OF DATA ON VOLCANISM IN THE GULF OF CADIZ
}

\author{
E Wulff-Barreiro ${ }^{1}$ \\ ${ }^{* 1}$ Marine Sciences Institute of Andalusia, Spanish National Research Council (CSIC), \\ Campus Universitario Rio San Pedro s/n, 11510 Puerto Real (Cádiz) \\ Email: enrique.wulff@icman.csic.es
}

\begin{abstract}
This paper reports the recent progress on mud volcanism data accumulation in the case of the Gulf of Cadiz area. The discovery of giant mud volcanoes, deep coral reefs, and gas hydrates in 1999, from the Guadalquivir Diapiric Ridge to the Larache Moroccan margin, launched a dynamic expansion of new projects (GeNesis, MoundForce, HERMES) and international oceanographic campaigns (R/V Sonne, Marion-Dufresne). The present monitoring of this Ibero-Moroccan oceanic zone is in need of a comprehensive database available in one site to make online search possible from a single interface. The database would constitute a reference point for a focused full scope collection.
\end{abstract}

Keywords: Volcanic gases, Data exchange, Mud volcanoes, Gas hydrates, Gulf of Cadiz, Methane, Databases

\section{$1 \quad$ INTRODUCTION}

Data about regional gas-charged sediments revealed a series of mud volcanoes in the Gulf of Cádiz, SW Spain (Ercilla \& Baraza, 1996). The gas hydrate content in sediments recovered from the deepest water depths, 2200 $\mathrm{m}-3060 \mathrm{~m}$, is $3-16 \%$ of the sediment volume and $5-31 \%$ of the pore space volume (Mazurenko, Soloviev, Belenkaya, Ivanov \& Pinheiro, 2002). Previous data derived from this search for deep gas, methane-caged in ice hydrates have been estimated by including the distribution of these structures in three areas: the Morocco margin, the Deep Portuguese margin, and the Iberian margin (Somoza, Diaz-del-Rio, Leon, Ivanov, FernándezPuga, Gardner et al., 2003; Díaz del Río, Somoza, Martinez-Frias, Mata, Delgado, Hernandez-Molina et al., 2003). The Iberian margin has differentiated two main fields: one in the surroundings of the Guadalquivir Diapiric System (GDS) and the other in the Central Slope, namely the Tasyo Area. Also, manganese nodules have been discovered at the base and flanks of mud-carbonate mounds and mud volcanoes in the Guadalquivir Diapiric Ridge Area (González, Somoza, Lunar, Martínez-Frías, Martín Rubí, Torres et al., 2008).

We wish to write a schema that essentially allows description of the data characterizing mud volcanoes, the literature that discusses their distribution, the explanation of the mechanisms by which they form, and the characteristics associated with hydrate accumulations. It is important to express that a submarine mud volcano is considered as an edifice, which has been built up by the eruption of mud breccia triggered by the vertical migration of hydrocarbon-rich fluids (Somoza, Diaz-del-Rio, Leon, Ivanov, Fernandez-Puga, Gardner et al., 2003). The elaboration of a universal lithological and genetic classification of recent mud volcanic deposits appears to be an interesting research target related to further scientific needs (Akhmanov, Ivanov, Woodside \& Cita, 2001). Indeed, if the present monitoring of this Ibero-Moroccan oceanic zone is missing a comprehensive database, it is due to the fact that none of the classification schemes proposed for mud volcanic deposits is universal. All of them have rational and reasonable arguments. However, only a universal classification can be taken as a basis for compiling a database of mud volcanic deposits.

Regarding the existing identification schemes for the mud volcanoes, some of the more recent paid attention to different granulometric parameters (Kroupskaia, Andreeva, Sergeeva, Cherkashev, Vogt, \& Ivanov, 2001). Others recognized main tipology on the basis of microstructural and microtextural characteristics of mud breccia (Akhmanov \& Woodside, 1998), attributing each lithological type of mud volcanic deposit to different depositional processes. In addition, based on primary observations of the core, mud breccie types were defined as pebby muds, polymictic gravels, or matrix-supported mud debris flow deposits. Excessive generalizations in the explanation of differences in lithology and the lack of sufficient detail in the classifications themselves have determined the absence of convergence to a universal classification.

A catalogue describing a field of mud volcanoes in the Gulf of Cadiz must consider some 40 buildings that have been identified by BSR (Bottom Simulating Reflector)-like reflections (Somoza, 2007). The name, latitude, 
longitude, water depth, length, width, area, and diameter constitute the elemental units of identification corresponding to the individual edifices. The size, shape, seismic artifacts, faulting, and relation to the underlying structure, collapse structure, mud flows, and timing of activity is the information that we consider necessary in order to have a good and accurate characterization.

Geochemical analyses of mud volcanoes gases from gas-hydrate aggregates consist of: location of water samples, date and identification, isotopic analysis of the water by mass spectrometry, and the chromatography of the gases after sediment extraction by means of ionization detectors. A structured representation of the geochemical data comprises estimations of gas emission during periods of quiescence and during violent eruptions, methane concentrations, etc.

This contribution is organized by first describing the bibliometrics of the Gulf of Cadiz mud volcanoes database, which consists of 208 references over a period of 25 years. In a second step, using all the literature data available, we give an exposition on how the data could be sorted to get a classification scheme. The objective is to offer an overview of the archives and availability of all mud volcanism data gathered by research facilities in the Gulf of Cádiz.

\section{BIBLIOMETRICS: JOURNAL COVERAGE, AUTHOR PRODUCTIVITY, CORE LITERATURE}

A good starting point for data exploration is represented by the analysis of such basic entities as authors' productivity and citations, which constitutes a bibliometric approach for quantitative analysis of the literature side (Kurtz, Eichhorn, Accomazzi, Grant, Demleitner, Murray, et al., 2003). An information facility such as a comprehensive database or data repository would be useful if its contents are described statistically, simplifying data harvesting and providing ready visualisation of data.

\subsection{Journal coverage}

The recent appearance of mud volcanism data gathered by research facilities in the Gulf of Cadiz can be viewed in Table 1, which lists the posting frequencies for searches for the four descriptors, 'mud volcano', 'volcanism', 'methane', and 'chimney', all in a conjunctive boolean equation with the geographic name 'Gulf of Cadiz'.

Table 1. Occurrences of search terms in Google, Google Scholar, the Web of Knowledge, and Scopus

\begin{tabular}{|l|l|l|l|l|}
\hline Term & Google & $\begin{array}{l}\text { Google } \\
\text { Scholar }\end{array}$ & $\begin{array}{l}\text { Web of } \\
\text { Knowledge }\end{array}$ & Scopus \\
\hline Mud volcano & 1710 & 207 & 23 & 414 \\
\hline Volcanism & 15100 & 504 & 8 & 422 \\
\hline Methane & 9360 & 319 & 19 & 861 \\
\hline Chimney & 544 & 47 & 1 & 64 \\
\hline
\end{tabular}

Conceptually, these data can be viewed from the perspective of their volume. Their restricted temporal evolution, from 1999 when the first data from the mud volcanoes explorations in the Gulf of Cadiz began to appear, limits the effect of data set consolidation on research collaboration (Martín-Sempere, Rey-Rocha, \& Garzón-García, 2002).

In Table 1, the Google occurrence frequencies show that while a subject of significant study can be directly selected, as the highest rates expressed are for 'Volcanism', the descriptor space can further be bounded by the relatively populous results searching for submarine 'Methane'. The Google Scholar data set has a similar qualitative result. Scopus clearly deserves attention because of the large number of entries with an interest in 'Methane'. Undoubtedly studies of bathyal ecosystems associated with carbonate chimneys are clearly a most probable source of data consistent with leading ranked information. The number of mud volcanoes discovered is more often quoted inside the Web of Knowledge, perhaps because many academics are obliged to document their citations for merit-based considerations (Redner, 1998). 
Articles on mud volcanoes, volcanism, methane, and chimneys in the Gulf may not contain these particular words, but clearly they are crucial as factors in play to focus on relevant data when considering their online and download availability. A search of all the fields in the Scopus database retrieved 208 citation sources, with 23 literature sources yielding a minimum of three documents as shown in Table 2.

Table 2. Most commonly occurring literature sources in a search of the Scopus for mud volcano, volcanism, methane, chimney, in the Gulf of Cádiz

\begin{tabular}{|l|c|}
\hline \multicolumn{1}{|c|}{ Citation source } & Number of \\
& documents \\
\hline Marine Geology & 26 \\
Geo-Marine Letters & 17 \\
Earth and Planetary Science Letters & 7 \\
Marine and Petroleum Geology & 7 \\
Terra Nova & 7 \\
Sedimentary Geology & 6 \\
Tectonophysics & 5 \\
Geological Society Special Publication & 5 \\
Journal of Geophysical Research B Solid Earth & 5 \\
Organic Geochemistry & 4 \\
Tectonics & 4 \\
Marine Geophysical Researches & 4 \\
Comptes Rendus Geoscience & 4 \\
Continental Shelf Research & 4 \\
Geophysical Journal International & 4 \\
Geochimica Et Cosmochimica Acta & 3 \\
Geofluids & 3 \\
Journal of Marine Systems & 3 \\
Journal of the Geological Society & 3 \\
Scientia Marina & 3 \\
Sedimentology & 3 \\
Zootaxa & 3 \\
Deep Sea Research Part II. Topical Studies in Oceanography & 3 \\
\hline
\end{tabular}

Of these documents, almost all are journal articles (181 of 208). Conference papers were just fifteen, and except for the OCEANS 2007 - Europe meeting and the 2001 Proceedings of the International Offshore and Polar Engineering Conference, all were published as journal papers. The list is dominated by Marine Geology thus confirming its use as a core journal for the subject. Aside from that source, the list contains 18 geological journals, with three journals covering general topics in oceanography (Scientia marina, Journal of Marine Systems, and Deep Sea Research Part II: Topical Studies in Oceanography) and one specialist journal covering topics that are enclosed in the area of taxonomy (Zootaxa). Ten review articles appear in four geological journals, one inside a multi-disciplinary journal (Science) and four in journals that publish relevant material found under queries on oceanography, climate, taxonomy and physics (Oceanography and Marine Biology, Palaeogeography Palaeoclimatology Palaeoecology, Physica D Nonlinear Phenomena and Zootaxa).

Citations from 96 journals were responsible in 1999-2008 for citations to the core journal Marine Geology. These included Geo Marine Letters, International Journal of Earth Sciences or Marine Geophysical Researches (and, in the first place, Marine Geology itself). The 161 journal cited by Marine Geology in the same period include Geo Marine Letters, Geology, and Technophysics (with in the first place Marine Geology itself). This data for citations to and references from Marine Geology shows that in spite of the brief time period, this is a major topic in its own right.

\subsection{Author productivity}

In Table 2, we have considered journals having a focus on the topic 'mud volcano in the Gulf of Cádiz'. An author analysis, however, will show its most productive researchers. The results of such analysis are shown in Table 3. For each journal in Table 3, we have listed the 10 most productive authors in the period, using the 
'Limit to' routines in Scopus. Each column contains an author name and the number of papers published in brackets under the names of the first ten specialist journals as identified in Table 2.

Table 3. The most productive authors in the first ten specialist journals are identified in Table 2. The number that follows each journal or author name, in brackets, is the number of documents published on 'Mud volcanoes in the Gulf of Cádiz' in that journal or by this author in the period 1999-2008.

\begin{tabular}{|c|c|c|c|c|c|c|c|}
\hline $\begin{array}{l}\text { Marine } \\
\text { Geology } \\
(26)\end{array}$ & $\begin{array}{l}\text { Geo Marine } \\
\text { Letters } \\
\text { (17) }\end{array}$ & $\begin{array}{l}\text { Earth and } \\
\text { Planetary } \\
\text { Science } \\
\text { Letters (7) }\end{array}$ & $\begin{array}{l}\text { Marine and } \\
\text { Petroleum } \\
\text { Geology (7) }\end{array}$ & $\begin{array}{l}\text { Terra Nova } \\
\text { (7) }\end{array}$ & $\begin{array}{l}\text { Sedimentary } \\
\text { Geology (6) }\end{array}$ & $\begin{array}{l}\text { Geological } \\
\text { Society } \\
\text { Special } \\
\text { Publication (5) }\end{array}$ & $\begin{array}{l}\text { Journal of } \\
\text { Geophysical } \\
\text { Research B } \\
\text { Solid } \\
\text { Earth (5) }\end{array}$ \\
\hline $\begin{array}{l}\text { Somoza, L. } \\
\text { (5) } \\
\text { Ivanov, M. } \\
\text { (4) } \\
\text { Fernández- } \\
\text { Puga, } \\
\text { M.C. (4) } \\
\text { Maestro, A. } \\
\text { (4) } \\
\text { Medialdea, } \\
\text { T. (3) } \\
\text { Vazquez, } \\
\text { J.T. (3) } \\
\text { Hernandez- } \\
\text { Molina, F.J. } \\
\text { (3) } \\
\text { Henriet, } \\
\text { J.P. (3) } \\
\text { Hovland, } \\
\text { M. (2) } \\
\text { Ivanov, } \\
\text { M.K. (2) }\end{array}$ & $\begin{array}{l}\text { Fernandez- } \\
\text { Puga, M.C. } \\
\text { (3) } \\
\text { Mata, M.P. } \\
\text { (3) } \\
\text { Garcia-Gil, } \\
\text { S. (3) } \\
\text { Somoza, L. } \\
\text { (3) } \\
\text { Medialdea, } \\
\text { T. (2) } \\
\text { Mulder, T. } \\
\text { (2) } \\
\text { Hanquiez, } \\
\text { V. (2) } \\
\text { Vazquez, } \\
\text { J.T. (2) } \\
\text { Leon, R. } \\
\text { (2) } \\
\text { Mazurenko, } \\
\text { L.L. (1) }\end{array}$ & $\begin{array}{l}\text { van den } \\
\text { Bogaard, P. } \\
\text { (1) } \\
\text { Yun, T.S. (1) } \\
\text { Wallmann, K. } \\
\text { (1) } \\
\text { Voelker, } \\
\text { A.H.L. (1) } \\
\text { Verges, J. } \\
\text { (1) } \\
\text { Tiberi, C. (1) } \\
\text { Schonfeld, J. } \\
\text { (1) } \\
\text { Santamarina, } \\
\text { J.C. (1) } \\
\text { Ruppel, C. } \\
\text { (1) } \\
\text { Reitz, A. (1) }\end{array}$ & $\begin{array}{l}\text { Lunar, R. } \\
\text { (1) } \\
\text { Martinez- } \\
\text { Frias, J. (1) } \\
\text { Mazzini, A. } \\
\text { (1) } \\
\text { Merinero, } \\
\text { R. (1) } \\
\text { Morales- } \\
\text { Puente, P. } \\
\text { (1) } \\
\text { Mortera- } \\
\text { Gutierrez, } \\
\text { C. (1) } \\
\text { Nermoen, } \\
\text { A. (1) } \\
\text { O'Brien, } \\
\text { P.E. (1) } \\
\text { Planke, S. } \\
\text { (1) } \\
\text { Prol- } \\
\text { Ledesma, } \\
\text { R.M. (1) }\end{array}$ & $\begin{array}{l}\text { Arboleya, } \\
\text { M.L. (3) } \\
\text { Teixell, A. } \\
\text { (3) } \\
\text { Mauffret, } \\
\text { A. (1) } \\
\text { Mazurenko, } \\
\text { L.L. (1) } \\
\text { Medialdea, } \\
\text { T. (1) } \\
\text { Missenard, } \\
\text { Y. (1) } \\
\text { Pinheiro, } \\
\text { L.M. (1) } \\
\text { Reiners, } \\
\text { P.W. (1) } \\
\text { Ruiz, G. } \\
\text { (1) } \\
\text { Saddiqi, O. } \\
\text { (1) }\end{array}$ & $\begin{array}{l}\text { Wilson, K. } \\
\text { (1) } \\
\text { Swennen, R. } \\
\text { (1) } \\
\text { Smith, H.D. } \\
\text { (1) } \\
\text { Piola, G. (1) } \\
\text { Ori, G.G. (1) } \\
\text { Morz, T. (1) } \\
\text { McKirdy, } \\
\text { D.M. (1) } \\
\text { Little, T. (1) } \\
\text { Kreiter, S. } \\
\text { (1) } \\
\text { Kopf, A. (1) }\end{array}$ & $\begin{array}{l}\text { Ziegler, P.A. } \\
(1) \\
\text { Woodside, } \\
\text { J.M. (1) } \\
\text { Viana, A.R. } \\
\text { (1) } \\
\text { Sultan, N. (1) } \\
\text { Stow, D.A.V. } \\
\text { (1) } \\
\text { Somoza, L. } \\
\text { (1) } \\
\text { Roure, F. (1) } \\
\text { Nunes, M.C.V. } \\
\text { (1) } \\
\text { Lopez, M. (1) } \\
\text { Llave, E. (1) }\end{array}$ & $\begin{array}{l}\text { de Lamotte, } \\
\text { D.F. (1) } \\
\text { Zeyen, H. } \\
\text { (1) } \\
\text { Van } \\
\text { Rensbergen, } \\
\text { P. (1) } \\
\text { Tassara, A. } \\
\text { (1) } \\
\text { Seeber, L. } \\
\text { (1) } \\
\text { Sebrier, M. } \\
\text { (1) } \\
\text { Schmidt, S. } \\
\text { (1) } \\
\text { Saddiqi, O. } \\
\text { (1) } \\
\text { Ryan, } \\
\text { W.B.F. (1) } \\
\text { Poort, J. (1) }\end{array}$ \\
\hline
\end{tabular}

\begin{tabular}{|l|l|}
\hline Tectonophysics (5) & $\begin{array}{l}\text { Organic } \\
\text { Geochemistry (4) }\end{array}$ \\
\hline Fernández, M. (2) & Sinninghe Damste, \\
Zeyen, H. (1) & J.S. (2) \\
Verges, J. (1) & Elvert, M. (2) \\
Torne, M. (1) & Stadnitskaia, A. (2) \\
Thiebot, E. (1) & Baas, M. (1) \\
Teson, E. (1) & Blinova, V. (1) \\
Teixell, A. (1) & Bouloubassi, I. (1) \\
Marzan, I. (1) & Hinrichs, K.U. (1) \\
Julivert, M. (1) & Hopmans, E. (1) \\
J vanov, M.K. (1) \\
Jenner, G.A. (1) & Milkov, A.V. (1) \\
& \\
\hline
\end{tabular}

Examination of the most productive authors indicates that three, Somoza, Medialdea, and Fernández-Puga, publish in three journals. Marine Geology, Geo Marine Letters had papers from all three, and the authors publish independently in Geological Society Special Publication, Terra Nova, and Tectonophysics. Therefore, user-oriented initiatives looking for data must retain the role these five journals have in terms of author productivity. Of considerable interest might be that with the textual data item 'methane', the most productive author is Gómez Parra.

A considerable degree of overlap between the journals occurs when exploring the four search results. The interdisciplinary context resides then in the journals Marine Geology (12 occurrences in the four searches), Geo Marine Letters (7), Terra Nova (5), Tectonophysics (5), Earth and Planetary Science Letters (5), and Tectonics (4). Using percentage of references to give us an idea of the relevant classification of the original data in terms of author productivity, the 9210 references that are cited by the 208 selected documents were estimated. Somoza is the best example of performance, with $57 \%$ of the quota shown by the ten most used authors, as measured by the occurence of their articles in the lists of references of other authors. 


\subsection{Core literature}

The most cited articles are presented in Table 4.

Table 4. Most cited articles in 10 top journals (those in Table 3) in 1996-2008

\begin{tabular}{|c|c|}
\hline Highly cited articles & Citations \\
\hline $\begin{array}{l}\text { Maldonado, A. et al. (1999), "The Betic orogen and the Iberian-African boundary in } \\
\text { the Gulf of Cadiz: Geological evolution (central North Atlantic)", Marine } \\
\text { Geology, Vol. } 155 \text { (1-2), pp. 9-43. }\end{array}$ & 66 \\
\hline $\begin{array}{l}\text { De Mol, B. et al. (2002), "Large deep-water coral banks in the Porcupine Basin, } \\
\text { southwest of Ireland", Marine Geology, Vol. } 188 \text { (1-2), pp. 193-231. }\end{array}$ & 60 \\
\hline $\begin{array}{l}\text { Duggen, S. et al. (2004), "Magmatic evolution of the Alboran region: The role of } \\
\text { subduction in forming the western Mediterranean and causing the Messinian } \\
\text { Salinity Crisis", Earth and Planetary Science Letters, Vol. } 218 \text { (1-2), pp. } 91 \\
\text {-108. }\end{array}$ & 43 \\
\hline $\begin{array}{l}\text { Pinheiro, L.M. et al. (2003), "Mud volcanism in the Gulf of Cadiz: Results from the } \\
\text { TTR-10 cruise", Marine Geology, Vol. } 195 \text { (1-4), pp. 131-151. }\end{array}$ & 43 \\
\hline $\begin{array}{l}\text { Díaz del Río, V. et al. (2003), "Vast fields of hydrocarbon-derived carbonate } \\
\text { chimneys related to the accretionary wedge/olistostrome of the Gulf of Cádiz", } \\
\text { Marine Geology, Vol. } 195 \text { (1-4), pp. 177-200. }\end{array}$ & 38 \\
\hline $\begin{array}{l}\text { Somoza, L. et al. (2003), "Seabed morphology and hydrocarbon seepage in the Gulf } \\
\text { of Cádiz mud volcano area: Acoustic imagery, multibeam and ultra-high } \\
\text { resolution seismic data", Marine Geology, Vol. } 195 \text { (1-4), pp. 153-176. }\end{array}$ & 36 \\
\hline $\begin{array}{l}\text { Fleischer, P. et al. (2001), "Distribution of free gas in marine sediments: A global } \\
\text { overview", Geo-Marine Letters, Vol. } 21 \text { (2), pp. 103-122. }\end{array}$ & 33 \\
\hline $\begin{array}{l}\text { Woodside, J.M. et al. (1998), "Shallow gas and gas hydrates in the Anaximander } \\
\text { Mountains region, eastern Mediterranean Sea", Geological Society Special } \\
\text { Publication, (137), pp. 177-193. }\end{array}$ & 30 \\
\hline $\begin{array}{l}\text { Medialdea, T. et al. (2004), "Structure and evolution of the "Olistostrome" complex } \\
\text { of the Gibraltar Arc in the Gulf of Cádiz (eastern Central Atlantic): Evidence } \\
\text { from two long seismic cross-sections", Marine Geology, Vol. } 209 \text { (1-4), pp. } \\
\text { 173-198. }\end{array}$ & 25 \\
\hline $\begin{array}{l}\text { Milkov, A.V. (2005), "Molecular and stable isotope compositions of natural gas } \\
\text { hydrates: A revised global dataset and basic interpretations in the context of } \\
\text { geological settings", Organic Geochemistry, Vol. } 36 \text { (5), pp. 681-702. }\end{array}$ & 23 \\
\hline $\begin{array}{l}\text { Gay, A. et al. (2003), "Sinuous pockmark belt as indicator of a shallow buried } \\
\text { turbiditic channel on the lower slope of the Congo basin, West African margin", } \\
\text { Geological Society Special Publication, Vol. 216, pp. 173-189. }\end{array}$ & 22 \\
\hline $\begin{array}{l}\text { Kvenvolden, K.A., Rogers, B.W. (2005), "Gaia's breath - Global methane } \\
\text { exhalations", Marine and Petroleum Geology, Vol. } 22 \text { (4 Spec. Iss.), pp. } 579 \\
\text {-590. }\end{array}$ & 20 \\
\hline $\begin{array}{l}\text { Cole, D. et al. (2000), "Giant irregular pockmark craters in the Palaeogene of the } \\
\text { outer Moray Firth Basin, UK North Sea", Marine and Petroleum Geology, Vol. } \\
17 \text { (5), pp. 563-577. }\end{array}$ & 20 \\
\hline $\begin{array}{l}\text { Judd, A.G. (2003), "The global importance and context of methane escape from the } \\
\text { seabed", Geo-Marine Letters, Vol. } 23 \text { (3-4), pp. 147-154. }\end{array}$ & 19 \\
\hline $\begin{array}{l}\text { Van Rensbergen, P. et al. (2005), "The El Arraiche mud volcano field at the } \\
\text { Moroccan Atlantic slope, Gulf of Cadiz ", Marine Geology, Vol. } 219 \text { (1), pp. 1- } \\
\text { 17. }\end{array}$ & 18 \\
\hline
\end{tabular}

Ranked in decreasing number of citations, these first fifteen documents can be used to determine the best parameter to index all papers if they were to be enclosed in a separate database. These data must be linked to the total number of citations (1940) contained in the complete set of documents cited (208). As the exploration of the sea mud volcanoes is notably technology-dependent, the code to determine the mean number of citations by document is not strangely low, with just a mean value of 24 for the complete set and 16 using only the first ten journals (as in Table 4).

The result is that none of the articles listed in Table 4, from their titles, offers criteria on the use of databases or software packages for an automatic data map. The American Geophysical Union policy of reducing free access 
to their corporate data could explain this. If characteristics of this investigation are the use of radiocarbon age calibration, fluctuating sea levels estimations, testing, and numerical and statistical models, the analysis must "shrink away" from the dimension of the citations to observe these descriptors. The absence of review articles is also interesting, as research profiling by reviewing the literature is an expression of the databases' existence.

\section{A DATABASE: MUD VOLCANOES}

Free access to mud volcanism and deep gas hydrate data coming from the Gulf of Cadiz requires a database service. Acceptable ranges of observed variables as a function of depth by basin include volcano names (synonyms and subsidiary features); mud volcanoes types, morphologies, and structures; latitude and longitude; water depth; mud volcanoes' elevation; craters; slope and moat; sedimentary structure; fauna collected in the mud volcanoes; mud volcanoes' images; composition of the gas hydrates; range of emitted methane; isotopic analysis of oxygen and hydrogen; and data sources (sample references and bibliographic samples).

A good model for the design of a data exchange platform is the data input form as prepared by the CODATA Gas Hydrate Data Task Group. It should be organized by distributing an initial recommendation on data schema based on three alternative methods: the hand entry of data, an entire data file, or data sets from a database. All options must follow a two-step procedure: metadata and data values entrances. To publish them on the web or an intranet the metadata entry comprises:

- $\quad$ Selection of the information for the depending measurements:

depending measurement (depth, time);

unit of depending measurement (meter, feet);

position of depending measurement (onshore, offshore).

- Selection of the measurement parameters and their unit:

gas mass spectrometer data;

gas chromatograph data

- Additional information:

number of data rows

The basic schema definition should allow extension of additional data fields to customize it to different needs, e.g., how to add electron microscopy data (images and chemical spectra) to a certain mud volcano gas flux emission (Reiter, 2007).

\subsection{General features}

A database of mud volcano data should support at least six basic research approaches:

Bibliographic

Mud volcano

Reduced mud volcano

Gas hydrate (formula)

Database entry lookup

Composite data search

For instance, the database lookup entry would provide an option to choose which database is to be searched where all field names are to be highlighted in order to get help on searching that field. An option to switch between forms should be available from the drop down menu.

\subsection{Mud volcanoes classification}

What is the proper classification scheme for mud volcanoes, as a universal classification does not exist and therefore quality control data can not be secured (Akhmanov \& Woodside, 1998)? Lineage statements are local and classification problems are explicitly considered only in one specific case (León, Somoza, Medialdea, Maestro, Diaz-del-Río, \& Fernández-Puga, 2006). This is an inherent limitation on the database design efficiency. Whatever the design strategy and network access configuration, the overall design must be done from the user's perspective with concern for the goals of interoperability. The database should leave a legacy of infrastructure within the control of the scientists, a specific audience with specific tasks in mind. 


\section{$4 \quad$ REFERENCES}

Akhmanov, G.G. \& Woodside, J.M. (1998) Mud volcanic samples in the context of the Mediterranean ridge mud diapiric belt. Proceedings Ocean Drilling Program (pp. 597-605), College Station, TX.

Akhmanov, G.G., Ivanov, M.K., Woodside, J.M., \& Cita, M.B. (2001) Lithology of deep-sea mud volcanic deposits: general assessment of current knowledge and future research needs. Geological processes on deepwater European margins : International conference and Ninth post-cruise meeting of the training-throughresearch programme, Moscow, Russia. Retrieved September 7, 2008 from the World Wide Web: http://unesdoc.unesco.org/images/0012/001242/124241eo.pdf

CODATA Gas Hydrate Data Task Group - data exchange platform. Retrieved from the WWW, February 23, 2009: http://www-app1.gfz-potsdam.de/ghml/index.php.

Diaz-del-Rio, V., Somoza, L., Martinez-Frias, J., Mata, M.P., Delgado, A., Hernandez-Molina, F.J., Lunar, R., Martin-Rubi, J.A., Maestro, A., Fernández-Puga, M.C., Leon, R., Llave, E., Medialdea, T., \& Vazquez, J.T. (2003) Vast fields of hydrocarbon-derived carbonate chimneys related to the accretionary wedge/olistostrome of the Gulf of Cadiz. Marine Geology, 195(1-4), 177-200.

Ercilla, G. \& Baraza, J. (1996) Evidencias de gas en los sedimentos del talud del Golfo de Cádiz. Geogaceta, 20, 180-183.

González, F.J., Somoza, L., Lunar, R., Martínez-Frías, J., Martín Rubí, J.A., Torres, T., Ortíz, J.E., León, R., Medialdea, T., \& Díaz del Río, V. (2008) Ferromanganese nodules in the Gulf of Cadiz: The hydrocarbon seepages and the Mediterranean Outflow Water undercurrent as mineralization controls. International Geological Congress, Oslo, Norway.

Kroupskaia, V.V., Andreeva, I.A., Sergeeva, E.I., Cherkashev, T.T., Vogt, P.R., \& Ivanov, M.K. (2001) The Haakon Mosby mud volcano (Norwegian sea): peculiarities of composition and structure of the deposits. Arctic99, Moscow, Russia.

Kurtz, M.J., Eichhorn, G., Accomazzi, A., Grant, C.S., Demleitner, M., Murray, S.S., Martimbeau, N., \& Elwell, B. (2003) The NASA Astrophysics Data System: Sociology, Bibliometrics, and Impact. Retrieved September 11, 2008 from the World Wide Web: http://cfa-www.harvard.edu/ kurtz/jasist-submitted.pdf

León, R., Somoza L., Medialdea T., Maestro A., Diaz-del-Río V., \& Fernández-Puga Mª C. (2006) Classification of sea-floor features associated with methane seeps along the Gulf of Cadiz continental margin. Deep-Sea Research, 11(53), 1464-1481.

Martín-Sempere, Ma. J., Rey-Rocha, J., \& Garzón-García, B. (2002). The effect of team consolidation on research collaboration and performance of scientists. Case study of Spanish university researchers in Geology. Scientometrics, 55(3), 377-394.

Mazurenko, L.L., Soloviev, V.A., Belenkaya, I., Ivanov, M.K., \& Pinheiro, L.M. (2002) Mud volcano gas hydrates in the Gulf of Cadiz. Terra nova 14(5), 321-329.

Redner, S. (1998). How popular is your paper? An empirical study of the citation distribution. Retrieved September 9, 2008 from the World Wide Web: http://arxiv.org/abs/cond-mat/9804163v1

Reiter, E. (2007) Volcanogasml: a format to exchange geochemical volcanic gases data. Data Science Journal 6(21), 7-18.

Somoza, L. (2007) informe cientifico/ tecnico campaña Moundforce N/O L'Atalante 23 Agosto / 9 Septiembre 2007. Retrieved September 14, 2008 from the World Wide Web: http://tierra.rediris.es/moundforce/

Somoza, L., Diaz-del-Rio, V., Leon, R., Ivanov, M., Fernández-Puga, M.C., Gardner, J.M., Hernandez-Molina, F.J., Pinheiro, L.M., Rodero, J., Lobato, A., Maestro, A., Vazquez, J.T., Medialdea, T., \& Fernandez-Salas, L.M. (2003) Seabed morphology and hydrocarbon seepage in the Gulf of Cadiz mud volcano area: Acoustic imagery, multibeam and ultra-high resolution seismic data. Marine Geology. 195(1-4), 153-176. 
Data Science Journal, Volume 8, 20 May 2009

(Article history: Received 10 November 2008, Accepted 20 February 2009, Available online 24 April 2009) 